\title{
ULTRASTRUCTURAL CHANGES IN Schistosoma mansoni MALE WORMS AFTER in vitro INCUBATION WITH THE ESSENTIAL OIL OF Mentha $x$ villosa Huds
}

\author{
Thiago José MATOS-ROCHA(1,4), Marília Gabriela dos Santos CAVALCANTI(2), Dyana Leal VERAS(1,4), Ana Paula Sampaio FEITOSA(1,4), \\ Gabriel Gazzoni Araújo GONÇALVES(1,4), Nairomberg Cavalcanti PORTELA-JUNIOR(1,4), Ana Silvia Suassuna Carneiro LÚCIO(2), Anekécia Lauro da SILVA(6), \\ Rafael José Ribeiro PADILHA(4), Márcia Ortiz Mayo MARQUES(3), José Maria BARBOSA-FILHO(2), Luiz Carlos ALVES(1,4,5) \& Fábio André BRAYNER(1,4)
}

\begin{abstract}
SUMMARY
Introduction: The essential oil Mentha $x$ villosa (MVEO) has a wide range of actions, including antibacterial, antifungal, antiprotozoal and schistosomicidal actions. The present study aimed to investigate the ultrastructural changes of MVEO on the tegument of adult Schistosoma mansoni. Materials and Methods: Different concentrations of MVEO were tested on S. mansoni adult worms in vitro. Ultrastructural changes on the tegument of these adult worms were evaluated using scanning electron microscopy (SEM) and transmission electron microscopy (TEM). Results: The MVEO caused the death of all worms at $500 \mu \mathrm{g} \mathrm{mL} \mathrm{m}^{-1}$ after 24 h. After $24 \mathrm{~h}$ of $500 \mu \mathrm{g} \mathrm{mL}-1$ MVEO treatment, bubble lesions were observed over the entire body of worms and they presented loss of tubercles in some regions of the ventral portion. In the evaluation by TEM, S. mansoni adult worms treated with MVEO, $500 \mu \mathrm{g}$ $\mathrm{mL}^{-1}$, presented changes in the tegument and vacuoles in the syncytial matrix region. Glycogen granules close to the muscle fibers were visible. Conclusion: The ability of MVEO to cause extensive ultrastructural damage to $S$. mansoni adult worms correlates with its schistosomicidal effects and confirms earlier findings with $S$. mansoni.
\end{abstract}

KEYWORDS: Schistosomicidal activity; Schistosoma mansoni; Mentha x villosa.

\section{INTRODUCTION}

Schistosomiasis is a neglected disease widespread worldwide and poses a major public health problem. It is caused by parasitic trematode flatworms of the Schistosoma genus; moreover, S. mansoni is the only species found in Brazil ${ }^{1,2}$.

The treatment of schistosomiasis is based on the use of praziquantel (PZQ); however, this drug seems ineffective against juvenile stages of $S$. mansoni and its extensive use in mass treatment of populations in schistosomiasis risk areas have favored the emergence of refractory strains of $S$. mansoni to conventional treatment with $\mathrm{PZQ}^{3}$.

Therefore, the search for new drugs that can act against $S$. mansoni becomes relevant, and tools such as scanning electron microscopy (SEM) and transmission electron microscopy (TEM) have been employed to study the effects of compounds on the tegument of many helminths, especially $S$. mansoni ${ }^{4}$. In this context, the search for natural bioactive compounds against $S$. mansoni becomes an interesting alternative ${ }^{2}$.

Mentha $x$ villosaHudson (Lamiaceae) has been used in traditional medicine due to its antiparasitic activity. It is known popularly as "hortelã- rasteira", "hortelã comum", or "hortelã-da-folha-miúda" ${ }^{5}$ Giamebil ${ }^{\circledR}$ is a commercial formulation presenting amebicidal (Entamoeba histolytica) and giardicidal (Giardia lamblia) activities, having as its active ingredient the dry extract from the leaves and stem of M. $x$ villos $a^{6}$. Recent studies have also demonstrated the efficacy of M. $x$ villosa against Trichomonas vaginalis ${ }^{7}$

Essential oils (EOs) and extracts of aromatic plants have been recognized for many years as a great source of pharmaceutical agents and food additives ${ }^{8}$. Some studies show different biological effects caused by the M. $x$ villosa essential oil (MVEO): antimicrobial ${ }^{9}$, hypotensive and bradycardiac ${ }^{10,11}$, cardiovascular ${ }^{12-14}$, larvicidal ${ }^{15}$, antinociceptive ${ }^{16}$, cytotoxic, antitumor ${ }^{17}$ and schistosomicidal activities ${ }^{18}$,

Recent studies developed by our research group have demonstrated the in vitro schistosomicidal activity of $\mathrm{MVEO}^{18}$. However, there are no studies showing ultrastructural changes in $S$. mansoni adult worms after incubation with MVEO.

The aim of this study was to evaluate the ultrastructural changes in $S$. mansoni male worms after in vitro incubation with MVEO; the results shown here are supported by TEM and SEM.

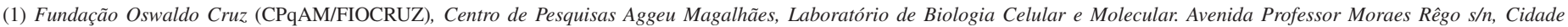
Universitária, 50740-465 Recife, Pernambuco, Brasil.

(2) Universidade Federal da Paraíba, Cidade Universitária s/n, 58051-900 João Pessoa, PB, Brasil.

(3) Centro de Recursos Genéticos Vegetais, Biologia Molecular e Fitoquímica, Instituto Agronômico de Campinas, 13001 -970 Campinas, São Paulo, Brasil.

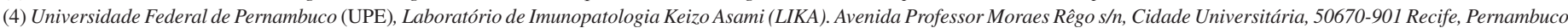
Brasil.

(5) Universidade de Pernambuco (UPE), Instituto de Ciências Biológicas, Rua Arnóbio Marques 310, 50100-130 Santo Amaro, PE, Brasil.

(6) Universidade Federal de Pernambuco (UPE), Laboratório de Planejamento e Síntese de Fármacos, 50670-901, Recife, Pernambuco, Brasil.

Correspondence to: Thiago José Matos- Rocha. E-mail: thy_rocha@ hotmail.com 


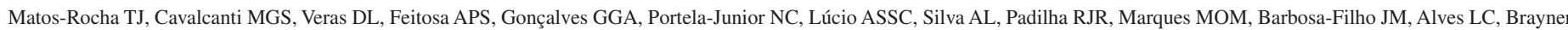
FA. Ultrastructural changes in Schistosoma mansoni male worms after in vitro incubation with the essential oil of Mentha x villosa Huds. Rev Inst Med Trop Sao Paulo. 2016;58:4.

\section{MATERIALS AND METHODS}

Ethics statement: All experiments involving the use of experimental animals were performed in accordance to the ethical standards of the Fundação Oswaldo Cruz and were approved by the Animal Experimentation Ethics Committee (No. 06/2010).

Botanical material: Fresh leaves of the species $M . x$ villosa were used. They were gathered from the Medicinal Plants Garden of the Laboratório de Tecnologia Farmacêutica, Universidade Federal da Paraiba between April and June 2011. They were identified and authenticated by Dr. F. J. Abreu Matos (Laboratório de Produtos Naturais, Universidade Federal do Ceará) and Dr. Raymond Harley of the Royal Botanic Gardens, Kew, England. A voucher specimen was deposited in the Prisco Bezerra Herbarium of the Federal University of Ceará (N. 14996).

Preparation of samples: To extract MVEO, $10 \mathrm{~kg}$ of leaves were steam-distilled for $8 \mathrm{~h}$. The oil obtained $(0.1 \%)$ was dried over anhydrous sodium sulfate in the usual manner and stored at $4{ }^{\circ} \mathrm{C}$. We used a gas chromatograph coupled to a mass spectrometer (Shimadzu QP-5000) under the following analytical conditions: capillary column, OV-5 $(30 \mathrm{~m}$ $\times 0.25 \mathrm{~mm} \times 0.25 \mu \mathrm{m}$ ); injector (Ohio Valley Specialty Chemical, Inc.), $240{ }^{\circ} \mathrm{C}$; detector, $230^{\circ} \mathrm{C}$; electron impact, $70 \mathrm{eV}$; gas drag, He; flow, 1.0 $\mathrm{mL} / \mathrm{min}$; split, $1 / 20$; program temperature, $60{ }^{\circ} \mathrm{C}-240{ }^{\circ} \mathrm{C}$ at $3{ }^{\circ} \mathrm{C} / \mathrm{min}$; and solution injection volume, $1 \mu \mathrm{L}(1 \mu \mathrm{L}$ of essential oil per $1 \mathrm{~mL}$ of ethyl acetate). The compounds were identified by comparing their mass spectra using the GC-MS database system (Nist 62 lib.) and the Kovats retention index. The compounds were dissolved in $100 \%$ dimethyl sulfoxide $(\mathrm{DMSO})^{18}$.

Praziquantel was commercially available through Sigma-Aldrich (Sigma chemical, St Louis, MO, USA) with purity of $99.9 \%$.

Obtaining and maintenance of $\boldsymbol{S}$. mansoni adult worms: The BH S. mansoni strain (Belo Horizonte, Minas Gerais, Brazil) was used throughout this study. This strain was maintained in Biomphalaria glabrata snails and Swiss Webster mice in a laboratory at the Centro de Pesquisas Aggeu Magalhães of Fundação Oswaldo Cruz. Female Swiss Webster mice weighing $20 \pm 5$ grams were used as the definitive host, and were infected transcutaneously with about 120 cercariae of the $\mathrm{BH}$ strain, -as previously described ${ }^{18}$, using the tail immersion technique. The animals were exposed for $1 \mathrm{~h}$ to the cercariae and they were subsequently kept under controlled temperature and light conditions. Furthermore, they had access to food and water ad libitum ${ }^{19}$.

After fifty-five days of infection, S. mansoni adult worms were recovered from the mice by perfusion, washed in RPMI 1640 medium buffered with HEPES (20 mM), pH 7.5, supplemented with penicillin (100 IU mL $\left.\mathrm{mL}^{-1}\right)$, streptomycin $\left(100 \mu \mathrm{g} \mathrm{mL}^{-1}\right)$, and $10 \%$ fetal bovine serum (Gibco), and placed in petri dishes containing $2 \mathrm{~mL}$ of sterile culture medium $^{20}$.

In vitro studies of $S$. mansoni adult worms: To assess the damage to the tegument, adult worms of $S$. mansoni were recovered from the hepatic portal system of the infected mice and left for a period of $2 \mathrm{~h}$ to adapt to the culture medium. MVEO isolate and compound was added in varying concentrations: a) $\operatorname{MVEO}\left(5,10,100,250\right.$, and $\left.500 \mu \mathrm{g} \mathrm{mL}^{-1}\right)$. Then, the worms were incubated at $37^{\circ} \mathrm{C}$ in an atmosphere containing $5 \% \mathrm{CO}_{2}{ }^{18}$.

As controls, S. mansoni adult worms were incubated in the presence of $1.6 \%$ DMSO in RPMI 1640 (negative control) or exposed to $0.5 \mu \mathrm{g}$ $\mathrm{mL}^{-1} \mathrm{PZQ}$ (positive control). All experiments were performed with three replicates. The final volume in each well was $2 \mathrm{~mL}$. The parasites were collected and monitored for routine processing with SEM and TEM at $24,48,72,96$, and $120 \mathrm{~h}$ intervals. The worms were considered dead when there was no motion detected after 3 minutes of observation. SEM and TEM were used as tools to evaluate the morphological changes in $S$. mansoni adult worms after in vitro exposure.

Transmission Electron Microscopy (TEM): S. mansoni adult worms in each group were fixed $(2.5 \%$ glutaraldehyde in sodium cacodylate buffer $0.1 \mathrm{M}, \mathrm{pH}$ 7.4). After fixation, they were washed with sodium cacodylate buffer $0.1 \mathrm{M}, \mathrm{pH} 7.4$, and postfixed with $1 \%$ osmium tetroxide $\left(\mathrm{OsO}_{4}\right)$, in the same buffer, for $2 \mathrm{~h}$ in the dark. Then, samples were washed, counterstained block with $5 \%$ uranyl acetate in water. Dehydration was performed in a series of increasing acetone $(30,50,70$, 90 and $3 \times 100 \%$ ) for $30 \mathrm{~min}$, each at room temperature and followed by embedding in Embed 812/Araldite resin (Electron Microscopy Sciences, Hartfield, PA) at $70{ }^{\circ} \mathrm{C}$ for $48 \mathrm{~h}$. Semi-thin sections were stained with toluidine blue for morphological observation, while ultrathin sections were subsequently contrasted in uranyl acetate for $1 \mathrm{~h}$ and lead citrate for $10 \mathrm{~min}$, and observations done in TEM (TEM 100CXII JEOL).

Scanning Electron Microscopy (SEM): The worms were incubated for $24 \mathrm{~h}$ and, after their death, they were washed with sodium cacodylate buffer $(\mathrm{pH}=7.2)$, fixed with $2.5 \%$ glutaraldehyde $(\mathrm{pH}=7.4)$ during $24 \mathrm{~h}$, and then fixed with $1 \%$ osmium tetroxide for $1 \mathrm{~h}$. The samples were dehydrated by an increasing amount of ethanol solution, dried in a critical point dryer, and then mounted on stubs and coated with gold using a sputter coater. The material was examined under a JEOL - 5600 LV microscope.

\section{RESULTS AND DISCUSSION}

The tegument of $S$. mansoni is an important structure for its survival since it is involved in nutrient absorption, secretion of metabolites, osmotic balance, and parasitic defense against the host immune system; this structure is an important target for drug action ${ }^{21}$. Some studies have documented damages to the tegument of $S$. mansoni caused by synthetic $^{22-24}$ and natural ${ }^{25-26}$ antischistosomal compounds.

Ultrastructural analysis was performed on male worms for two reasons: females are frequently in contact with the host microenvironment and studies in the literature have shown that soft tissue alterations are more pronounced in males than in female worms ${ }^{27}$.

\section{Ultrastructural analysis of MVEO-induced surface damage in S. mansoni}

Scanning Electron Microscopy (SEM): Control groups were not affected for up to five days of observation and all worms exhibited vigorous activity. It can be seen that male worms of $S$. mansoni in the control group presented the tegument covered with tubercules and tiny projections (spines). The back was long and contained the gynecophoral canal $(\mathrm{gc})$. The area between the oral and ventral suckers did not have 


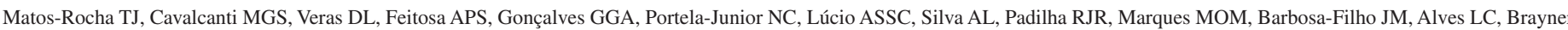
FA. Ultrastructural changes in Schistosoma mansoni male worms after in vitro incubation with the essential oil of Mentha x villosa Huds. Rev Inst Med Trop Sao Paulo. 2016;58:

any tubercles (tu), spines (sp) or sensory papillae (Fig. 1A-1B). The presence of a large number of tubercles with typical spines (Fig. 1C) as well as sensory papillae (st) (Fig. 1D) was observed.

In assessing the viabitility of the worms treated with $\mathrm{PZQ}$, it was observed the death of all worms after $24 \mathrm{~h}$ of incubation. Using SEM, it was identified that the $S$. mansoni adult worms treated with PZQ $(0.5$ $\mu \mathrm{g} \mathrm{mL}-1$ ) showed spiraled body (Fig. 1E). In the tegument there was destruction of tubercules and spines, and many regions with ulceration (Fig. 1F).
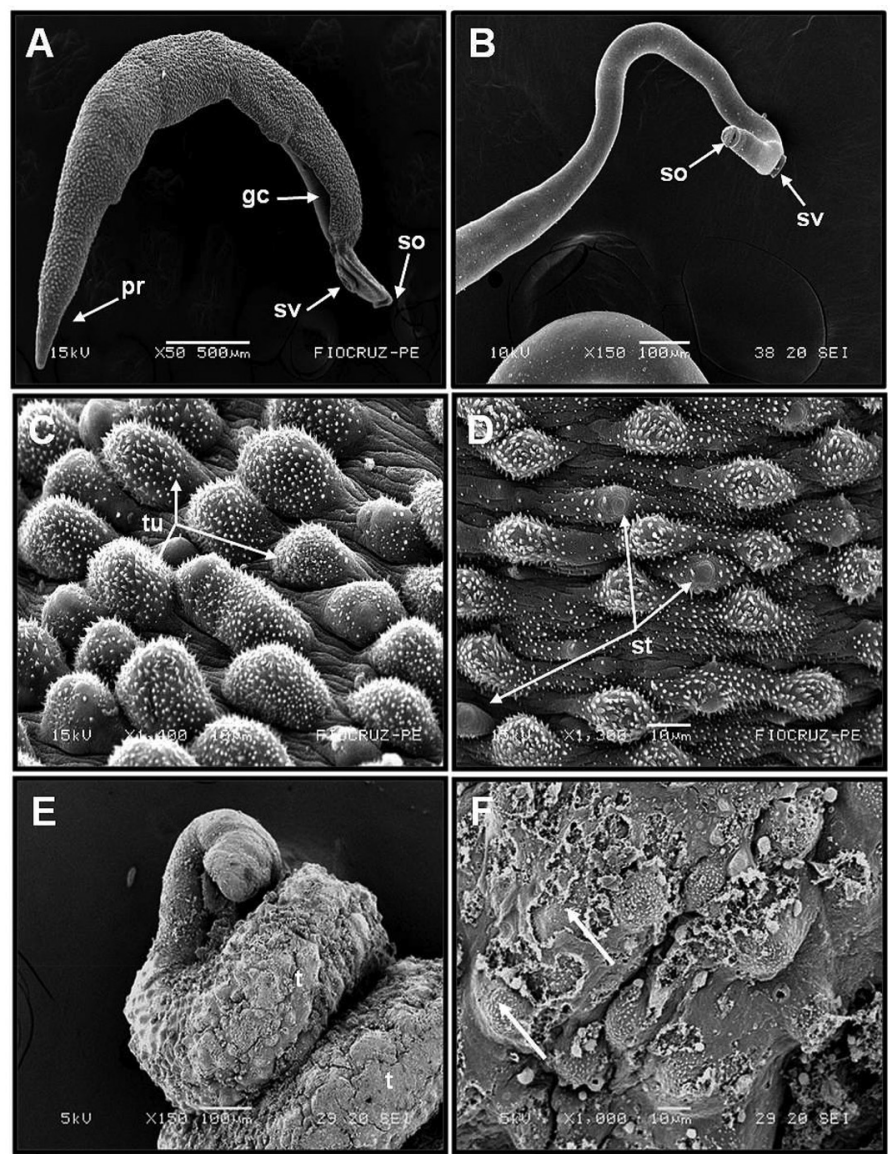

Fig. 1 (A-D) Electromicrographs of adult worms of S. mansoni without treatment. (A) Gynecophoric canal $(\mathrm{gc})$, thinner portion of the worms located in the posterior region (pr), (B) while in the anterior region are located the oral (so) and ventral (sv) suckers. (C) In the tegument of male worms the presence of tubercles (tu) with spines was observed. (D) The presence of a large number of tubercles with typical spines, randomly distributed throughout the body (st) was identified. (E-F) Electromicrographs of adult male worms of S. mansoni

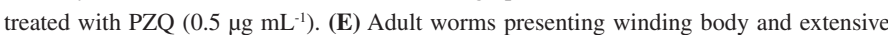
destruction of the tegument (t). (F) Severe damage on the tegument with loss of spines and extensive ulceration with muscle exposition (arrows).

After $24 \mathrm{~h}$ of MVEO $\left(500 \mu \mathrm{g} \mathrm{mL} \mathrm{m}^{-1}\right)$ treatment, bubble lesions were spread over the entire body of the worms (Fig. 2A), and the worms showed loss of tubercules in some regions of the ventral portion (Fig. 2B). After $48 \mathrm{~h}$ of incubation at $250 \mu \mathrm{g} \mathrm{mL}^{-1}$, death of worms was observed, destroyed the oral sucker had been destroyed and the ventral sucker contracted (Fig. 2C). Tegument lesion severity increased after $72 \mathrm{~h}$ of MVEO treatment $\left(100 \mu \mathrm{g} \mathrm{mL} \mathrm{mL}^{-1}\right)$, which caused the basal membrane to become unprotected (Fig. 2D). Lower concentrations (5 and $10 \mu \mathrm{g} \mathrm{mL}^{-1}$ ) were unable to cause mortality of $S$. mansoni adult worms after $120 \mathrm{~h}$ of exposure; however, changes in the tegument of the worms were recorded. At a concentration of $10 \mu \mathrm{g} \mathrm{mL}^{-1}$, tegument erosion can be visualized at higher magnification (Fig. 2E) and in the worms treated with $5 \mu \mathrm{g} \mathrm{mL}$ there was destruction of some tubercules (Fig. 2F).
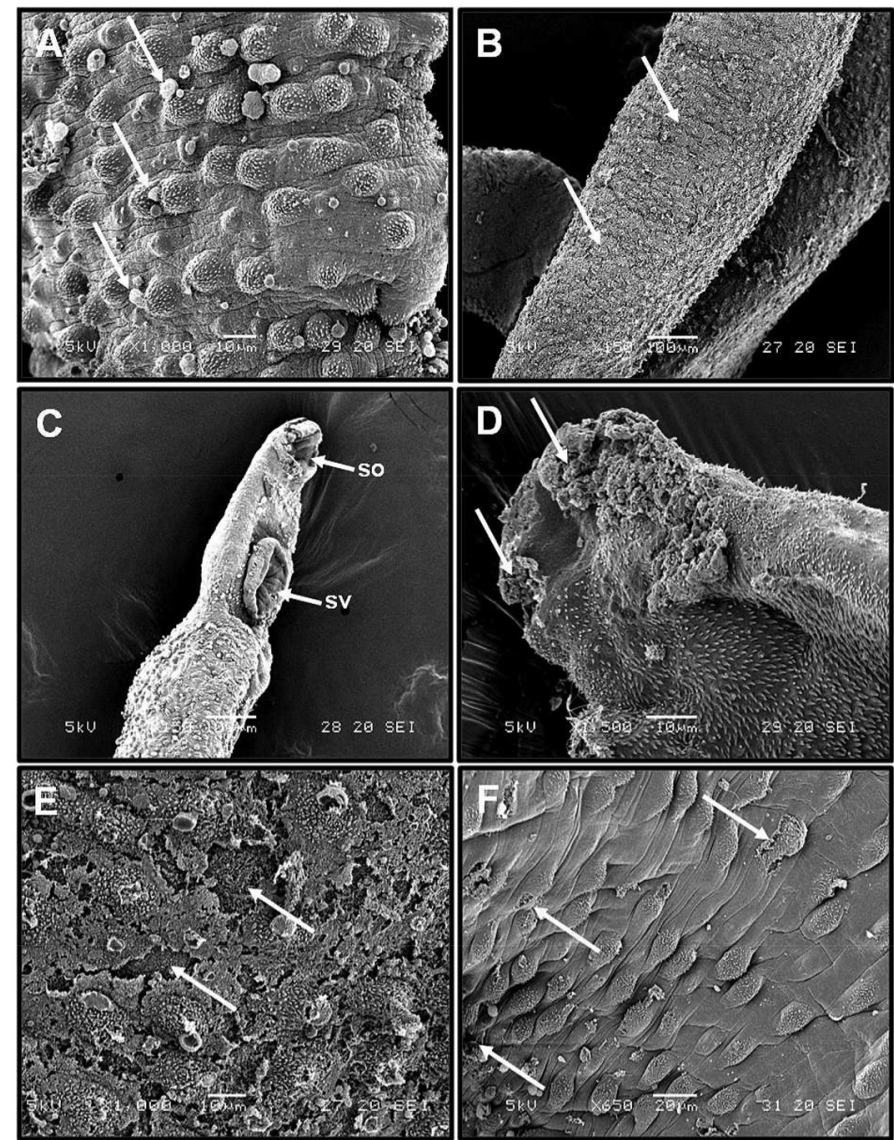

Fig. 2 (A-F). Electromicrographs of S. mansoni adult male worms of treated with different concentrations of MVEO. (A) After $24 \mathrm{~h}$ of MVEO $\left(500 \mu \mathrm{g} \mathrm{mL}^{-1}\right)$ treatment, bubble lesions were spread over the entire body of the worms (arrow). (B) Ventral portion of the adult worms of $S$. mansoni after $24 \mathrm{~h}$ of incubation with MVEO $\left(500 \mu \mathrm{g} \mathrm{mL}^{-1}\right)$. The loss of tubercules in some regions was observed (arrows). (C) Anterior region of the adult male worms $48 \mathrm{~h}$ after incubation with $250 \mu \mathrm{g} \mathrm{mL}^{-1}$ of MVEO. Destruction of the oral (os) and ventral (vs) suckers. (D) Tegument lesion severity increased (arrows) after $72 \mathrm{~h}$ of MVEO treatment $(100 \mu \mathrm{g} \mathrm{mL}$ $\left.{ }^{1}\right)$. (E) Tegument erosion (arrows) can be visualized at a higher magnification with no spines after $96 \mathrm{~h}$ of exposure to $10 \mu \mathrm{g} \mathrm{mL}^{-1}$ of MVEO. (F) Destruction of some tubercules after 120 $\mathrm{h}$ of incubation with $5 \mu \mathrm{g} \mathrm{mL} \mathrm{m}^{-1}$ of MVEO (arrows).

Transmission Electron Microscopy (TEM): The ultrastructural evaluation of $S$. mansoni adult worms by TEM revealed the presence of spines, characteristical matrix syncytial, and circular and longitudinal muscles in the subtegumentary region of the worms (Fig. 3A). The TEM analysis of $S$. mansoni adult worms treated with PZQ showed many changes like vacuoles in tuber, presence of vesicles in the syncytial matrix, and mesenchymal vacuolization (Fig. 2B).

In the evaluation by TEM, the $S$. mansoni adult worms treated with MVEO (500 $\left.\mu \mathrm{g} \mathrm{mL}^{-1}\right)$ presented changes in the tegument and presence 


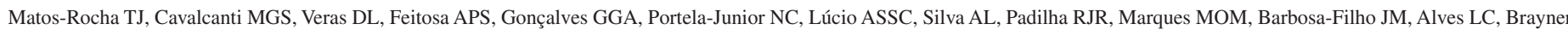
FA. Ultrastructural changes in Schistosoma mansoni male worms after in vitro incubation with the essential oil of Mentha $x$ villosa Huds. Rev Inst Med Trop Sao Paulo. 2016;58:4.

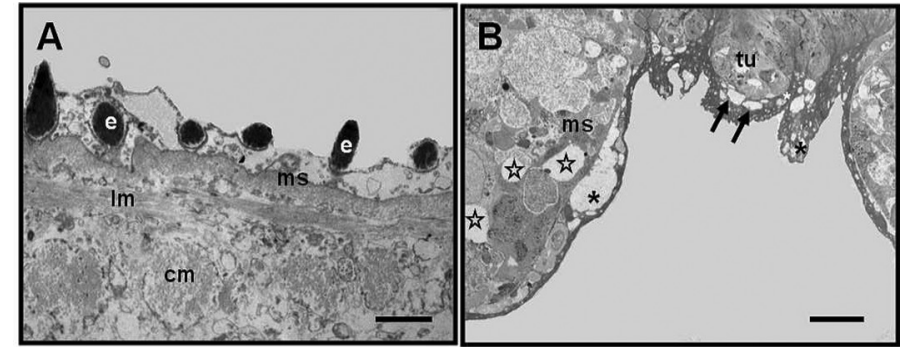

Fig. 3 (A-B). Electromicrographs of S. mansoni adult worms visualized by TEM. (A) In the control group, observe the spines (e). In the tegument, it is possible to identify the matrix syncytial (ms) and, in the subtegumentary region, it is possible to visualize the circular $(\mathrm{cm})$ and longitudinal ( $\mathrm{lm}$ ) muscles. (B) In the group treated with PZQ $\left(0.5 \mu \mathrm{g} \mathrm{mL} \mathrm{m}^{-1}\right)$ vacuoles (arrows) are observed in the tubercules (tu), presence of vesicles (asterisks) in the matrix syncytial (ms) and vacuolated mesenchymal (stars). Bars $=1 \mu \mathrm{m}$.

of vacuoles in the syncytial matrix region. It was visible the presence of glycogen granules close to the muscle fibers (Fig. 4). Essential oils are highly enriched with compounds termed terpenoids that possess several biological properties such as schistosomicidal activity ${ }^{21-25,28-30}$. In recent years, a number of studies have been developed through in vitro screening using essential oils, extracts, and bioactive compounds from medicinal plants ${ }^{27,29-32}$, to identify a leading substance that can be used in preclinical trials for the treatment of experimental schistosomiasis ${ }^{33-36}$.

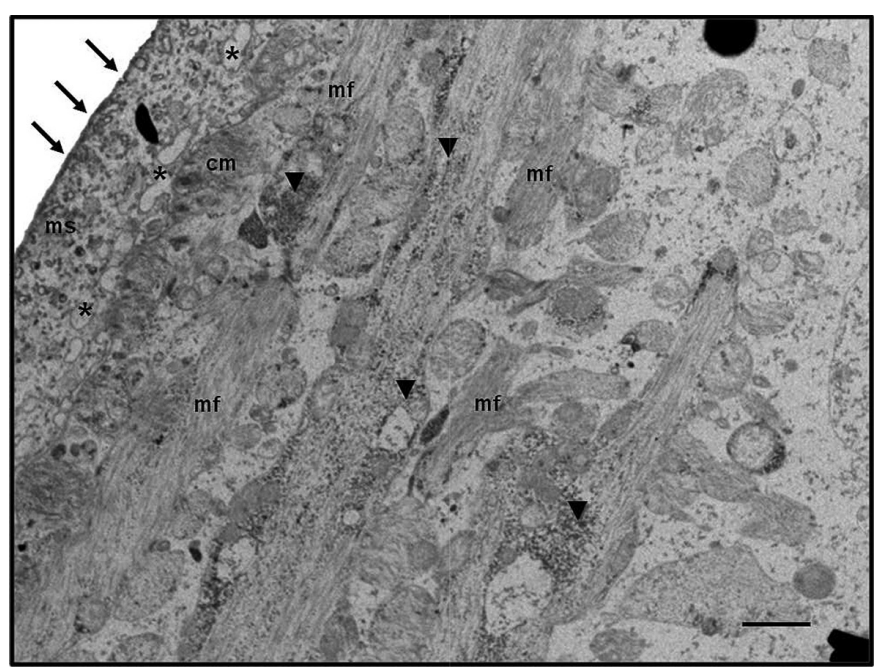

Fig. 4. Electromicrographs of adult worms of S. mansoni treated with MVEO $\left(500 \mu \mathrm{g} \mathrm{mL}^{-1}\right)$. Observe changes in the tegument (arrows) and vacuoles (asterisks). In the matrix syncytial (ms), it is even possible to identify accumulation of glycogen granules (arrowheads) around muscle fibers $(\mathrm{mf})$ and circular muscle $(\mathrm{cm})$. Bar $=1 \mu \mathrm{m}$

Generally, there was a marked difference between the morphology of worms treated with PZQ compared with MVEO, and compounds used individually. In the macroscopic examination, the $S$. mansoni adult worms, when exposed to PZQ, presented muscle contractions causing them to stay retracted or twisted. However, this behavior was not observed in the worms treated with MVEO or their constituents.

The adult worms incubated for $24 \mathrm{~h}$ with MVEO $(500 \mu \mathrm{g} \mathrm{mL}-1)$ showed damaged tegument and exposed musculature in some worms.
These findings were identified by LORSUWANNARAT et al. ${ }^{37}$ when testing plumbagin $\left(100 \mu \mathrm{g} \mathrm{mL}^{-1}\right)$ in $S$. mansoni adult worms. EISSA et $a l .{ }^{24}$ paid attention to this same finding when evaluating the effect of miltefosine $\left(10 \mu \mathrm{g} \mathrm{mL}^{-1}\right)$ on $S$. mansoni adult worms; however, the authors made observations after $120 \mathrm{~h}$ of incubation. LIMA et al. ${ }^{4}$, when assessing the effects of allicin on the tegument of S. mansoni, describe the occurrence of ulceration on the parasite tegument after 120 minutes of incubation with $20 \mu \mathrm{g} \mathrm{mL}^{-1}$ of MVEO. Previously, BERTÃO et al ${ }^{38}$ also evaluated the effects of miltefosine on $S$. mansoni adult worms by testing $200 \mu \mathrm{M}$ and found the same results; however, they used only 12 $\mathrm{h}$ of incubation.

In the present study, after $48 \mathrm{~h}$ of incubation with $250 \mu \mathrm{g} \mathrm{mL} \mathrm{m}^{-1}$ of MVEO, morphological changes in the oral sucker and ventral suckers of $S$. mansoni adult worms were observed. Comparable to our findings, ALBUQUERQUE et al. ${ }^{22}$ describe similar changes by treating $S$. mansoni with (Z)-3-(4-chloro-benzyl)-5-(4-nitro-benzylidene)-imidazolidine-2,4dione $\left(120 \mu \mathrm{g} \mathrm{mL}^{-1}\right)$; however, this data was observed following five days of incubation. OLIVEIRA et al. ${ }^{39}$ draw attention to the occurrence of damage in the oral sucker of $S$. mansoni adult worms after exposure to the essential oil of Baccharis trimera $\left(130 \mathrm{mg} \mathrm{mL}^{-1}\right)$ after $24 \mathrm{~h}$ of exposure. NEVES et $\mathrm{al}^{2}{ }^{2}$ only observed the contraction of the ventral sucker when evaluating a derivative of thioxo-imidazolidine $(100 \mu \mathrm{M})$ on $S$. mansoni adult worms after $3 \mathrm{~h}$ of incubation. KEISER et $a .^{40}$ also reported erosion of the tegument of female worms after exposure to mefloquine $\left(10 \mu \mathrm{g} \mathrm{mL}^{-1}\right)$ after $1 \mathrm{~h}$ of incubation. Our results show that the lowest concentration of MVEO ( 5 and $10 \mu \mathrm{g} \mathrm{mL}^{-1}$ ) caused less damage to soft tissue compared to the highest concentrations. The worms incubated in these concentrations generally showed destruction of tubercules with no spines. The same finding was observed by MANNECK et al. ${ }^{41}$ when assessing the effects of mefloquine $\left(10 \mu \mathrm{g} \mathrm{mL}^{-1}\right)$ on the tegument of $S$. mansoni adult worms. Recently, NEVES et al. ${ }^{2}$, while evaluating a thioxo-imidazolidine, determined that after less than $1 \mathrm{~h}$, adult $S$. mansoni vesicles showed that the increased number of these vesicles was proportional to the time of evaluation.

The mechanism by which MVEO exerts its in vitro anti-S. mansoni action is unclear. However, it has been reported that, because of the great different classes of compounds, usually essential oils may have no specific cellular target. Essential oils are typical lipophilic compounds, thus, the chemical substances of the oil, may pass through the cell wall, tegument, and cytoplasmic membrane damaging their structures and cellular membranes, which may lead to cellular lysis ${ }^{23}$. Regarding the therapeutic benefits of essential oils, so far, there are no studies that can give us a clear idea, or be accurate, about the mode of action. However, some effects are associated with loss of ions and reduction of membrane potential, as well as collapse of the proton pump and depletion of the ATP pool $^{23}$. Furthermore, it has to be kept in mind that essential oils are complex mixtures of volatile constituents biosynthesized by plants ${ }^{28}$. The present study showed that these MVEO are capable of producing a range of ultrastructural changes in the $S$. mansoni tegument. Therefore, considering the anti-S. mansoni action of MVEO, it may be possible that the activity of its main constituents can be modulated by molecules present in the essential oil.

\section{CONCLUSIONS}

The ability of MVEO to cause extensive ultrastructural damage to 
Matos-Rocha TJ, Cavalcanti MGS, Veras DL, Feitosa APS, Gonçalves GGA, Portela-Junior NC, Lúcio ASSC, Silva AL, Padilha RJR, Marques MOM, Barbosa-Filho JM, Alves LC, Brayner FA. Ultrastructural changes in Schistosoma mansoni male worms after in vitro incubation with the essential oil of Mentha x villosa Huds. Rev Inst Med Trop Sao Paulo. 2016;58:4.

S. mansoni adult worms correlates with its schistosomicidal effects and confirms earlier findings with $S$. mansoni.

\section{ACKNOWLEDGMENTS}

The authors thank LTF/UFPB, LIKA/UFPE and Núcleo de Plataformas Tecnológicas (NPT) of Aggeu Magalhães Research Center of the Oswaldo Cruz Foundation for supporting the experiments and CAPES for a scholarship.

\section{REFERENCES}

1. Neves BJ, Andrade CH, Cravo PVL. Natural products as leads in schistosome drug discovery. Molecules. 2015;20:1872-903.

2. Neves JK, Lima MCA, Pereira VRA, De Melo CML, Peixoto CA, Pitta IR, et al Antischistosomal action of thioxo-imidazolidine compounds: an ultrastructural and cytotoxicity study. Exp Parasitol. 2011;128:82-90.

3. Liang YS, Coles GC, Doenhoff MJ, Southgate VR. Susceptibility to praziquantel of male and female cercariae of praziquantel-resistant and susceptible isolates of Schistosoma mansoni. Int J Parasitol. 2001;31:202-7.

4. Lima CM, Freitas FI, Morais LC, Cavalcanti MG, Silva LF, Padilha RJ, et al. Ultrastructural study on the morphological changes to male worms of Schistosoma mansoni after in vitro exposure to allicin. Rev Soc Bras Med Trop. 2011;44:327-30.

5. Matos FJA, Machado MIL, Craveiro AA, Alencar JW, Barbosa JM, Cunha EVL, Himura $\mathrm{CH}$. Plants used in traditional medicine of China and Brazil. J Essent Oil Res. 1991;2:13-6.

6. Teles NSB, Fechine FV, Viana FAC, Viana IOL, Nascimento DF, Leite ALAS, et al Evaluation of the therapeutic efficacy of Mentha crispa in the treatment of giardiasis. Contemp Clin Trials. 2011;32:809-13.

7. Moraes ME, Cunha GH, Bezerra MM, Fechine FV, Pontes AV, Andrade WS, et al. Efficacy of the Mentha crispa in the treatment of women with Trichomonas vaginalis infection. Arch Gynecol Obstet. 2012; 286:125-30.

8. Joy B, Rajan A, Abraham E. Antimicrobial activity and chemical composition of essential oil from Hedychium coronarium. Phytother Res. 2007;21:439-43.

9. Arruda TA, Antunes RMP, Catão RMR, Lima EO, Sousa DP, Nunes XP, et al. Preliminary study of the antimicrobial activity of Mentha $x$ villosa Hudson essential oil rotundifolone and its analogues. Rev Bras Farmacogn. 2006;16:307-11.

10. Guedes DN, Silva DF, Barbosa-Filho JM, Medeiros IA. Calcium antagonism and the vasorelaxation of the rat aorta induced by rotundifolone. Braz J Med Biol Res. 2004a;37:1881-7.

11. Guedes DN, Silva DF, Barbosa-Filho JM, Medeiros IA. Endothelium-dependent hypotensive and vasorelaxant effects of the essential oil from aerial parts of Mentha $x$ villosa in rats. Phytomedicine. 2004b;11:490-7.

12. Lahlou S, Carneiro-Leão RF, Leal-Cardoso JH. Cardiovascular effects of the essential oil of Mentha x villosa in DOCA-salt-hypertensive rats. Phytomedicine. 2002; 9:715-20.

13. Lahlou S, Carneiro-Leão RF, Leal-Cardoso JH, Toscano CF. Cardiovascular effects of the essential oil of Mentha $x$ villosa and its main constituent, piperitenone oxide, in normotensive anaesthetised rats: role of the autonomic nervous system. Planta Med. 2001;67:638-43

14. Lahlou S, Magalhães PJC, Carneiro-Leão RFL, Leal-Cardoso JH. Involvement of nitric oxide in the mediation of the hypotensive action of the essential oil of Mentha $x$ villosa in normotensive conscious rats. Planta Med. 2002;68:694-9.
15. Lima, TC, da Silva TK, Silva FL, Barbosa-Filho JM, Marques MO, Santos RL, et al Larvicidal activity of Mentha $x$ villosa Hudson essential oil, rotundifolone and derivatives. Chemosphere. 2014;104:37-43.

16. Sousa PJC, Linard CFBM, Azevedo-Batista D, Oliveira AC, Coelho-de-Souza AN, LealCardoso JH. Antinociceptive effects of the essential oil of Mentha x villosa leaf and its major constituent piperitenone oxide in mice. Braz J Med Biol Res. 2009,42:655-9.

17. Amaral RG, Fonseca CS, Silva TK, Andrade LN, França ME, Barbosa-Filho JM, et al Evaluation of the cytotoxic and antitumour effects of the essential oil from Mentha villos $a$ and its main compound, rotundifolone. J Pharm Pharmacol. 2015[Epub ahead print] doi. 10.111/jphp.12409.

18. Matos-Rocha TJ, Cavalcanti MGS, Barbosa-Filho JM, Lúcio ALSC, Veras DL, Feitosa APS, et al. In vitro evaluation of schistosomicidal activity of essential oil of Mentha villosa and some of its chemical constituents in adult worms of Schistosoma mansoni. Planta Med. 2013;79:1307-12.

19. Smithers SR, Terry RJ. The infection of laboratory hosts with cercariae of Schistosoma mansoni and the recovery of the adult worms. Parasitology. 1965;55:695-700.

20. Aires AL, Ximenes EC, Silva RA, Barbosa VX, Góes AJ, Peixoto CA, et al. Ultrastructural analysis of -lapachone-induced surface membrane damage in male adult Schistosoma mansoni BH strain worms. Exp Parasitol. 2014;142:83-90.

21. Faghiri Z, Skelly PJ. The role of tegumental aquaporin from the human parasitic worm, Schistosoma mansoni, in osmoregulation and drug uptake. FASEB J. 2009;23:2780-9.

22. Albuquerque MCP, Pitta MGR, Irmão JI, Peixoto CA, Malagueño E, Santana JV, et al. Tegumental alterations in adult Schistosoma mansoni treated with imidazolidine derivatives. Lat Am J Pharm. 2007;26:65-9.

23. Bakkali F, Averbeck S, Averbeck D, Idaomar M. Biological effects of essential oils-a review. Food Chem Toxicol. 2008;46:446-75

24. Eissa MM, EL-Azzouni MZ, Amer EI, Baddour NM. Miltefosine, a promising novel agent for schistosomiasis mansoni. Int J Parasitol. 2011;41:235-42.

25. Esperandim VR, da Silva FD, Sousa RKC, Magalhães LG, Medeiros SJ, Pauletti PM, et al. In vitro antiparasitic activity and chemical composition of the essential oil obtained from the fruits of Piper cubeba. Planta Med. 2013;79:1653-5.

26. Godinho LS, Aleixo de Carvalho LS, Barbosa de Castro CC, Dias MM, Pinto PF, Crotti AE, et al. Anthelmintic activity of crude extract and essential oil of Tanacetum vulgare (Asteraceae) against adult worms of Schistosoma mansoni. Scientific WorldJournal. 2014(2014):460342.

27. Mostafa OM, Soliman MI. Experimental use of black-seed oil against Schistosoma mansoni in albino mice: II. Surface topography of adult worms. Egypt J Med Lab Sci. 2002;11:79-85

28. Moraes J, de Oliveira RN, Costa JP, Junior AL, de Sousa DP, Freitas RM, et al. Phytol, a diterpene alcohol from chlorophyll, as a drug against neglected tropical disease Schistosomiasis mansoni. PLoS Negl Trop Dis. 2014;8:e2617.

29. Moraes J de, Nascimento C, Lopes PO, Nakano E, Yamaguchi LF, Kato MJ, et al Schistosoma mansoni: in vitro schistosomicidal activity of piplartine. Exp Parasitol. 2011;127:357-64

30. Guimarães MA, de Oliveira RN, Véras LM, Lima DF, Campelo YD, Campos SA, et al Anthelmintic activity in vivo of epiisopiloturine against juvenile and adult worms of Schistosoma mansoni. PLoS Negl Trop Dis. 2015;9:e0003656.

31. Magalhães LG, Kapadia GJ, da Silva Tonuci LR, Caixeta SC, Parreira NA, Rodrigues $\mathrm{V}$, et al. In vitro schistosomicidal effects of some phloroglucinol derivatives from Dryopteris species against Schistosoma mansoni adult worms. Parasitol Res. 2010 106:395-401 
Matos-Rocha TJ, Cavalcanti MGS, Veras DL, Feitosa APS, Gonçalves GGA, Portela-Junior NC, Lúcio ASSC, Silva AL, Padilha RJR, Marques MOM, Barbosa-Filho JM, Alves LC, Brayner FA. Ultrastructural changes in Schistosoma mansoni male worms after in vitro incubation with the essential oil of Mentha x villosa Huds. Rev Inst Med Trop Sao Paulo. 2016;58:4.

32. Moraes J, Nascimento C, Yamaguchi LF, Kato MJ, Nakano E. Schistosoma mansoni: in vitro schistosomicidal activity and tegumental alterations induced by piplartine on schistosomula. Exp Parasitol. 2012;132:222-7.

33. Sass DC, Morais GO, Miranda RA, Magalhães LG, Cunha WR, dos Santos RA, et al. Structurally modified natural sesquiterpene lactones constitute effective and less toxic schistosomicidal compounds. Org Biomol Chem. 2014;12:7957-64.

34. Santos AF, Fonseca AS, César FA, de Azevedo Albuquerque MCP, Santana JV, Santana AEG. A penta-substituted pyridine alkaloid from the rhizome of Jatropha elliptica (Pohl) Muell. Arg. is active against Schistosoma mansoni and Biomphalaria glabrata. Parasitol Res. 2014;113:1077-84.

35. Silva AP, Silva MP, Oliveira CG, Monteiro DC, Pinto PL, Mendonça RZ, et al. Garcinielliptone FC: antiparasitic activity without cytotoxicity to mammalian cells. Toxicol In Vitro. 2015;29:681-7.

36. Veras LM, Guimaraes MA, Campelo YD, Vieira MM, Nascimento C, Lima DF, et al. Activity of epiisopiloturine against Schistosoma mansoni. Curr Med Chem. 2012;19:2051-8.
37. Lorsuwannarat N, Saowakon N, Ramasoota P, Wanichanon C, Sobhon P. The anthelmintic effect of plumbagin on Schistosoma mansoni. Exp Parasitol. 2013;133:18-27.

38. Bertão HG, Silva RAR, Padilha RJR, Albuquerque MCPA, Rádis-Baptista G. Ultrastructural analysis of miltefosine-induced surface membrane damage in adult Schistosoma mansoni BH strain worms. Parasitol Res. 2012;110:2465-73.

39. Oliveira RN, Rehder VLG, Oliveira ASS, Montanari Júnior I, Carvalho JE, Ruiz ALTG, et al. Schistosoma mansoni: in vitro schistosomicidal activity of essential oil of Baccharis trimera (less) DC. Exp Parasitol. 2012;132:135-43.

40. Keiser J, Chollet J, Xiao SH, Mei JY, Jiao PY, Utzinger J, et al. Mefloquine an aminoalcohol with promising antischistosomal properties in mice. PLoS Negl Trop Dis. 2009;3:e350.

41. Manneck T, Haggenmüller Y, Keiser J. Morphological effects and tegumental alterations induced by mefloquine on schistosomula and adult flukes of Schistosoma mansoni. Parasitology. 2010;137:85-98.

Received: 14 September 2014

Accepted: 29 May 2015 